doi: 10.32620/oikit.2021.91.03

УДК 621.98 .043

А. В. Онопченко

\title{
Структура дослідження енергосилових параметрів процесів листового штампування
}

\author{
Національний аерокосмічний університет ім. М. Є. Жуковського \\ «Харківський авіаційний інститут»
}

\begin{abstract}
Одним з головних завдань теоретичного дослідження $є$ виявлення оптимальних умов деформування. Найбільший інтерес для практики становить визначення основних технологічних параметрів процесу формоутворення і встановлення їх зв'язку із зовнішніми факторами. Вирішення цього питання $€$ дуже важливим і відповідальним етапом теоретичного дослідження і нерозривно пов'язане з вибором методу теоретичного аналізу і розрахункової схеми, яка найбільш повно задовольняє вимоги і умови конкретного випадку формоутворення. У статті розглянуто структуру комплексних теоретичних і експериментальних досліджень енергосилових параметрів технологічних процесів листового штампування-витяжки. Для ефективного прогнозування енергосилових параметрів запропоновано математичну модель, основану на побудованій структурно-логічній схемі, яка визначає методи і послідовність теоретичних і експериментальних досліджень і відображає взаємозв'язок функціональних характеристик процесу з технологічними параметрами режимів оброблення під час листового штампування-витяжки. Визначено характер формозмінення, який забезпечують пластичні деформації у процесах оброблення металів тиском. Визначено, що втрата стійкості заготовки або її руйнування накладають обмеження на ступінь допустимого формозмінення, яке визначається полем напружень в осередку деформацій. Запропоновано метод розрахунку процесів пластичного деформування металів на основі замкнутої системи рівнянь механіки суцільного середовища для теоретичного дослідження енергосилових параметрів технологічних процесів листового штампування. Досліджено вид функціональної залежності швидкості частинок пластично деформованого матеріалу від координат у процесі листового штампуваннявитяжки. Проаналізовано вирази, що дозволяють відтворити просторову картину розподілу деформації у металі при листовому штампуванні. Це дозволяє наочно уявити механізм деформації та спростити аналіз деформованого стану матеріалу. Показано зв'язок функції швидкості і функції дисипації енергії при знаходженні повної роботи деформації, яка дозволяє визначити силові параметри процесу листового штампування-витяжки. Досліджено функціональний взаємозв'язок між потужністю деформації і параметрами режимів оброблення при листовому штампуванні. Розглянуто підходи до визначення деформованого стану матеріалу.

Ключові слова: листове штампування-витяжка, енергосилові параметри процесу, оброблення металів тиском, система рівнянь механіки суцільного середовища, швидкість деформації, інтенсивність деформації, поле швидкостей частинок металу.
\end{abstract}

Корозійностійкі жароміцні й жаростійкі сплави, які широко застосовуються в авіадвигунобудуванні та мають високу міцність у поєднанні з великою в'язкістю, належать до категорії важкооброблюваних матеріалів різанням. Крім того, жароміцні сплави схильні до значного зміцнення поверхневого шару при обробленні лезовим інструментом, що призводить до збільшення сил різання і прискореного спрацювання різального інструменту. Тому одним з основних напрямків розвитку сучасної технології виробництва деталей авіаційних двигунів є зменшення обсягів технологічних процесів із зняттям шару металу і їх замінення процесами точного поверхневого і об'ємного фрормування деталей з наступним мінімальним механічним обробленням.

При операціях листового штампування пластичні деформації, що забез- 
печують заданий характер фрормозмінення, зазвичай мають місце лише у частині заготовки - осередку деформації. Поле напружень і деформацій в осередку деформації неоднорідне, тобто напруження в осередку деформації $є$ функцією координат у кожний момент деформування [1].

Значення і розподіл напружень в осередку деформації залежать від багатьох факторів, пов'язаних з розмірними характеристиками заготовки та інструменту, контактними умовами деформування, температурно-швидкісними умовами деформування тощо [1, 2].

Ступінь допустимого фрормозмінення у фрормозмінних операціях листового штампування обмежується або руйнуванням заготовки, або втратою нею стійкості, що призводить до неприпустимого викривлення форми.

Оскільки зусилля деформування, а іноді і ступінь допустимого фрормозмінення визначаються полем напружень в осередку деформацій, то встановлення розподілу напружень і енергосилових параметрів в осередку деформацій має бути одним з основних завдань при розгляді операцій листового штампування [3].

Для ефективного прогнозування енергосилових характеристик різних видів оброблення тиском, у тому числі й листового штампування, необхідно розробити математичні моделі, що відображають взаємозв'язок функціональних характеристик процесу з технологічними параметрами режимів оброблення. Правильна побудова моделі можлива, якщо буде розроблено структурнологічну схему, яка визначає методи і послідовність теоретичних і експериментальних досліджень.

Розрахунок осередку деформування потребує введення гіпотези про суцільність, а основним завданням кінематики течії в цьому випадку є визначення поля швидкостей частинок. Для отримання шуканих рівнянь, що описують поле швидкостей при листовому штампуванні, можна використовувати традиційні методи координатних сіток, накладення потоків або конформних перетворень. Кожен із зазначених вище методів має недоліки і потребує введення припущень, які іноді кардинально викривляють фрізичну картину процесу. Так, наприклад, метод координатних сіток передбачає визначення функції струму шляхом апроксимації ліній руху частинок металу, отриманих на підставі експериментальних даних. У зв'язку з цим він досить незручний і його не можна вважати на універсальним [4].

Метод накладення потоків теж не задовольняє наші вимоги через громіздкість і який не є простим і зручним. Крім того, метод накладення, як і потужний метод конформних перетворень, що базується на математичному апараті теорії функції комплексної змінної, придатний для визначення поля швидкостей потенціальних течій. Цього цілком достатньо для вирішення аеродинамічних задач в теорії легкообтічних тіл, але він не коректний у разі течії металу при листовому штампуванні-витяжці, оскільки пружно-пластичне деформування листового матеріалу неминуче спричиняє рух різних дефектів кристалічної будови, що призводить до дисипації енергії деформування з практично повним ії̈ перетворенням на тепло, а отже, і до значних сил внутрішнього тертя, нехтувати якими в цьому випадку не можна. Наявність значних сил внутрішнього тертя допускає обертання частинок металу в процесі деформування, а сам рух у такому випадку не можна вважати потенціальним [4].

У зв'язку з цим виникла необхідність розроблення методу отримання полів швидкостей процесу листового штампування, який повною мірою відображає 
фрізику процесу і при цьому досить простий і прийнятний для інженерних розрахунків.

Найбільш придатними для розрахунку процесів пластичної деформації $€$ методи, основані на замкнутій системі рівнянь механіки суцільного середовища, які запропоновано та розроблено у роботах Ю. М. Алексєєва [1, 2]. У цьому випадку метал, що деформується, розглядається як ідеалізоване суцільне середовище з усередненими механічними властивостями реального металу.

Теоретичний аналіз більшості технологічних процесів поряд з проведеними експериментами дозволяє визначити характер залежності швидкості руху частинок пластично деформованого металу від координат. Швидкість частинок може бути подана через вектор швидкості [2]:

$$
\vec{V}=v_{x} \vec{i}+v_{y} \vec{j}+v_{z} \vec{k}
$$

Поле швидкостей з урахуванням його нестисливості у цій області має бути соленоїдним або вихровим [4]:

$$
\operatorname{div} \overrightarrow{\mathrm{v}}=0 ; \quad \operatorname{rot} \overrightarrow{\mathrm{v}} \neq 0 .
$$

Використовуючи рівняння (1) і (2), можна визначити вид функціональної залежності швидкості від координат. Таким чином, визначається поле швидкостей частинок матеріалу, що дозволяє розраховувати швидкості деформації і їх інтенсивність за формулами:

$$
\begin{aligned}
& \varepsilon_{q_{1} q_{1}}=\frac{1}{H_{1}} \frac{\partial V_{q_{1}}}{\partial q_{1}}+\frac{V_{q_{2}}}{H_{1} H_{2}} \frac{\partial H_{1}}{\partial q_{2}}+\frac{V_{q_{3}}}{H_{1} H_{3}} \frac{\partial H_{1}}{\partial q_{3}} \\
& \varepsilon_{q_{1} q_{2}}=\frac{1}{H_{2}} \frac{\partial V_{q_{1}}}{\partial q_{2}}+\frac{1}{H_{1}} \frac{\partial V_{q_{2}}}{\partial q_{1}}-\frac{V_{q_{1}}}{H_{1} H_{2}} \frac{\partial H_{1}}{\partial q_{1}}-\frac{V_{q_{2}}}{H_{1} H_{2}} \frac{\partial H_{2}}{\partial q_{1}},
\end{aligned}
$$

де $\mathrm{q}_{1}, \mathrm{q}_{2}, \mathrm{q}_{3}$ - ортогональні криволінійні координати.

У цьому випадку виконуються рівняння зв'язку:

$$
\begin{aligned}
& x=x\left(q_{1}, q_{2}, q_{3}\right), y=y\left(q_{1}, q_{2}, q_{3}\right), z=z\left(q_{1}, q_{2}, q_{3}\right) ; \\
& H_{k}=\sqrt{\sum_{i=1}^{3}\left(\frac{\partial x_{i}}{\partial q_{k}}\right)^{2} ;} \\
& \varepsilon_{i}=\frac{\sqrt{3}}{2} \sqrt{\begin{array}{l}
\left(\varepsilon_{q_{1} q_{1}}-\varepsilon_{q_{2} q_{2}}\right)^{2}+\left(\varepsilon_{q_{2} q_{2}}-\varepsilon_{q_{3} q_{3}}\right)^{2}+\left(\varepsilon_{q_{3} q_{3}}-\varepsilon_{q_{1} q_{1}}\right)^{2}+ \\
+\frac{3}{2}\left(\varepsilon_{q_{1} q_{2}}^{2}+\varepsilon_{q_{2} q_{3}}^{2}+\varepsilon_{q_{3} q_{1}}^{2}\right) .
\end{array}}
\end{aligned}
$$

Тут $\mathrm{H}_{\mathrm{k}}$ - коефріцієнти Ламе.

Потім необхідно визначити складові деформації, щоб знайти параметри енергосилового процесу

та інтенсивність деформації

$$
\begin{aligned}
& e_{11}=\int \varepsilon_{11} d t, \\
& e_{22}=\int \varepsilon_{22} d t
\end{aligned}
$$

$$
e_{i}=\frac{\sqrt{3}}{2} \sqrt{\left(e_{11}-e_{22}\right)^{2}+\left(e_{22}-e_{33}\right)^{2}+\left(e_{33}-e_{11}\right)^{2}+\frac{3}{2}\left(e_{12}^{2}+e_{23}^{2}+e_{31}^{2}\right)} .
$$


Важливою характеристикою процесів оброблення металів тиском є робота деформації, яка дозволяє визначати силові параметри. Повна робота деформації визначається інтеграцією елементарної роботи за об'ємом U:

$$
A=\iiint \int_{v}\left(\rho V \frac{\partial V}{\partial t}+P_{x} \frac{\partial V}{\partial x}+P_{y} \frac{\partial V}{\partial y}+P_{z} \frac{\partial V}{\partial z}\right) d \nu d t .
$$

Дві функції було введено в [2]. Перша називається функцією швидкості

$$
L=\rho V \frac{\partial V}{\partial t} .
$$

Частина рівняння (5) виражає функцію дисипації енергії

$$
E=P_{x} \frac{\partial V}{\partial x}+P_{y} \frac{\partial V}{\partial y}+P_{z} \frac{\partial V}{\partial z} .
$$

Функція швидкості - це робота, спрямована на збільшення кінетичної енергії елементарного об'єму металу в процесі деформації. Функція розсіювання енергії полягає в тому, що частина роботи сприяє власній деформації матеріалу. Беручи до уваги рівняння (6) і (7), перепишемо рівняння (5) у такому вигляді:

$$
A=\iiint \int_{t}(L+E) d v d t .
$$

Якщо деформація здійснюється з малою швидкістю, то функція швидкості має досить мале значення порівняно з функцією дисипації енергії і нею можна знехтувати. У цьому випадку робота деформації буде визначатися через функцію дисипації енергії:

$$
A=\iiint \int_{v} E d v d t .
$$

Робота деформації елементарного об'єму металу, віднесена до октаедричних вузлів, має такий вигляд:

$$
d A=3 \tau_{o c t} \gamma_{o c t} d v d t,
$$

де тосt - напруження зсуву на октаедричній ділянці, тобто платформі, нахиленій до головних осей; Үoct - швидкість октаедричної деформації. Октаедричне напруження пов'язане з інтенсивністю напруження як

$$
3 \tau_{\text {oct }}=\sqrt{2} \sigma_{i} .
$$

Рівняння, що пов'язує швидкість октаедричної деформації з інтенсивністю швидкості деформації, має вигляд

$$
\gamma_{\text {oct }}=\frac{1}{\sqrt{2}} \varepsilon_{i} .
$$

Підставляючи рівняння (11) і (12) у рівняння (10) та інтегруючи останнє за об'ємом і часом, отримуємо:

$$
A=\iiint \int_{t} \sigma_{i} \varepsilon_{i} d v d t .
$$

Порівнявши формули (9) і (13), можна знайти, що

$$
E=\sigma_{i} \varepsilon_{i} .
$$

Для визначення потужності дефрормації функцію дисипації енергії (14) необхідно проінтегрувати тільки за об’ємом 


$$
N=\iiint_{v} E d v .
$$

Таким чином, можна визначити поле напружень, деформацій і енергосилові параметри процесу, використовуючи основні закони пластичної деформації і рівняння механіки суцільного середовища, якщо відомі складові швидкості частинок деформованого металу в процесі листового штампування.

\section{Список літератури}

1. Алексеев, Ю.Н. Вопросы пластического течения металлов [Текст] / Ю. Н. Алексеев. - Харьков : Изд-во ХГУ, 1958. - 187 с.

2. Алексеев, Ю. Н. Введение в теорию обработки металлов давлением, прокаткой и резанием [Текст] / Ю. Н. Алексеев. - Харьков : Изд-во ХГУ, 1969. 107 c.

3. Изготовление заготовок деталей газотурбинных двигателей из титановых сплавов [Текст] / В. А. Богуслаев [и др.]. - Запорожье : ОАО «Мотор Сич», 2000. -290 c.

4. Kurin M. O. Determination of the Boundaries of Plastic Zone of Metal Deformation During the Cutting, Progress in Physics of Metals. - 2020. - V. 21, No. 2. P. 249-273.

\section{Referenses}

1. Alekseev, Ju. N. Voprosy plasticheskogo techenija metallov [Tekst] / Ju. N. Alekseev. - Har'kov : Izd-vo HGU, 1958. - 187 s.

2. Alekseev, Ju. N. Vvedenie v teoriju obrabotki metallov davleniem, prokatkoj i rezaniem [Tekst] / Ju. N. Alekseev. - Har'kov : Izd-vo HGU, 1969. - 107 s.

3. Izgotovlenie zagotovok detalej gazoturbinnyh dvigatelej iz titanovyh splavov [Tekst] / V. A. Boguslaev [i dr.]. - Zaporozh'e : OAO «Motor Sich», 2000. - 290 s.

4. Kurin M. O. Determination of the Boundaries of Plastic Zone of Metal Deformation During the Cutting, Progress in Physics of Metals. -2020 . - V. 21, No. 2. P. 249-273.

Надійшла до редакції 13.03.2021, розглянута на редколегії 13.03.2021

\section{The Structure of Study of Energy Parameters of Sheet Metal Stamping Processes}

One of the main tasks of theoretical research is to identify optimal conditions for deformation. The greatest interest for practice is determination of main technological parameters of shaping process and their connection with external factors. The solution to the problem is a very important and crucial stage of theoretical investigation. It is inextricably linked with choosing theoretical method of analysis and design scheme, which most fully meets requirements and particular case of shaping conditions. The article discusses structure of complex theoretical and experimental investigations sheet drawing energy-power parameters of technological processes. Mathematical model has been proposed based on the constructed structural-logical scheme for effective forecasting of energy-power parameters, which determines 
methods and sequence of theoretical and experimental researches. It reflects correlation between functional characteristics of machining and technological parameters of the sheet stamping-drawing. The character of shaping has been determined, which is provided by plastic deformations in the processes of metal working by pressure. It has been determined that loss workpiece stability or its destruction impose restrictions on allowable deformation degree, which is defined in the deformation zone by stress field. Method for calculating processes of plastic deformation metals is proposed which it is using to theoretical investigation energy-power parameters of technological processes of sheet stamping. It is based on closed system equations of continuum mechanics. The form of particles velocity functional dependence of plastically deformable material on coordinates in stamping-drawing process of sheet has been determined. Expressions are analyzed which make it possible to make the spatial picture distribution of deformation in metal during sheet stamping. This allows visualizing deformation mechanism and simplifying the analysis material deformed state. The relationship between velocity and energy dissipation function is shown at total work deformation is found, which makes it possible to determine force parameters of sheet stamping-drawing process. A functional relationship between the deformation power and the parameters of processing modes during sheet stamping has been investigated. Approaches to determining deformed material state are considered.

Keywords: sheet metal stamping-drawing, power parameters of the process, processing of metals by pressure, system of equations of continuum mechanics, deformation rate, deformation intensity, velocity field of metal particles.

\section{Відомості про авторів:}

Онопченко Антон Віталійович - старший викладач кафедри технологій виробництва авіаційних двигунів та енергетичних установок, Національний аерокосмічний університет ім. М. Є. Жуковського «Харківський авіаційний інститут», м. Харків, Україна, A.Onopchenko@khai.edu, ORCID: 0000-0002-9004-4140.

\section{About the Author:}

Onopchenko Anton - Senior Lecturer of Department of Aircraft Engines and Power Plant Production Technologies, National Aerospace University "Kharkiv Aviation Institute”, Kharkiv, Ukraine, A.Onopchenko@khai.edu, ORCID: 0000-0002-90044140 . 